\title{
Apakah Ekspansi Kredit Perbankan Dan Peranan Ekspor Berpengaruh Terhadap Pertumbuhan Ekonomi? Jurnal Ecces
}

\author{
Andi Ika Fahrika ${ }^{1}$ \\ Institut Agama Islam Negeri (IAIN) Bone \\ Jl. Hos. Cokroaminoto No. Telp (0481) 21395 Fax. (0481) 23928 \\ Email : ikamur@yahoo.com
}

\section{Abstrak: Apakah Ekspansi Kredit Perbankan Dan Peranan Ekspor Berpengaruh Terhadap Pertumbuhan Ekonomi?}

Pertumbuhan ekonomi nasional saat ini, setidaknya diperhadapkan dengan delapan masalah besar. Resiko ketidakpastian ekonomi global, rendahnya daya beli masyarakat, menurunnya produktivitas nasional, realisasi kredit yang melambat, meningkatnya pengangguran, ketergantungan pada ekspor komoditas, efektivitas paket kebijakan fiskal dan moneter serta tantangan masyarakat ekonomi ASEAN. Dengan demikian, sektor usaha di Indonesia mesti berkembang agar pertumbuhan ekonomi nasional juga ikut bertumbuh dan mampu menjawab masalah-masalah tersebut. Makin banyak kredit usaha yang dikucurkan berarti hal tersebut merupakan bagian dalam rangka meningkatkan usaha nasional. Kredit sangat baik, jika kredit yang disalurkan untuk keperluan ekspor, karena dengan ini para eksportir dapat berproduksi secara maksimal sehingga volume ekspor meningkat yang akhirnya bertambah pula cadangan devisa sehingga pendapatan nasional bisa mengalami kenaikan. Penelitian ini bertujuan mengetahui (1). pengaruh ekspansi kredit perbankan terhadap ekspor di Indonesia, (2). pengaruh ekspansi kredit perbankan terhadap pertumbuhan ekonomi di Indonesia, (3). pengaruh ekspor terhadap pertumbuhan ekonomi di Indonesia, (4). pengaruh ekspansi kredit perbankan terhadap pertumbuhan ekonomi di Indonesia melalui ekspor. Data yang dianalisis adalah data sekunder dengan time series (2002-2016). Metode yang digunakan dalam penelitian ini adalah model persamaan struktural (SEM) dengan menggunakan data time series dari tahun 2002 - 2016. Hasil penelitian menunjukkan bahwa (1) ekspansi kredit perbankan berpengaruh positif secara langsung dan signifikan terhadap ekspor (2) ekspansi kredit perbankan berpengaruh positif secara langsung dan signifikan terhadap pertumbuhan ekonomi., (3) ekspor tidak berpengaruh secara langsung dan berpengaruh negatif terhadap pertumbuhan ekonomi (4) ekspansi kredit perbankan berpengaruh secara tidak langsung (melalui ekspor) terhadap pertumbuhan ekonomi.

Kata Kunci: Ekspansi Kredit Perbankan, Ekspor, Pertumbuhan Ekonomi 


\section{Abstract: Do Banking Credit Expansion And The Role of Exports Affecting To The Economic Growth?}

The current national economic growth, at least faced with eight major problems. Risk of global economic uncertainty, low public purchasing power, declining national productivity, slower credit realization, rising unemployment, reliance on commodity exports, the effectiveness of fiscal and monetary policy packages and the challenge of the ASEAN economic community. Thus, the business sector in Indonesia must grow so that national economic growth also grows and is able to answer those problems. The more business credit that is disbursed means it is a part in order to improve the national business. Very good credit, if credit is channeled for export purposes, because with this the exporters can produce maximally so that the volume of exports increases which eventually also increase the foreign exchange reserves so that the national income can increase. This study aims to determine (1). the effect of banking credit expansion on exports in Indonesia, (2). the effect of banking credit expansion on economic growth in Indonesia, (3). the effect of exports on economic growth in Indonesia, (4). the effect of banking credit expansion on economic growth in Indonesia through exports. The data analyzed is secondary data with time series (2002-2016). The method used in this research is a model of structural equation (SEM) using time series data from 2002 to 2016. The results of the research show that (1) the expansion of bank credit has a direct and significant positive effect on exports (2) credit expansion has a positive effect directly and significantly to economic growth, (3) exports have no direct and negative effect on economic growth (4) credit expansion indirectly (through export) to economic growth.

Keywords: Credit Expansion Banking, Export, Growth.

\section{PENDAHULUAN / INTRODUCTION}

Pertumbuhan ekonomi nasional saat ini, setidaknya diperhadapkan dengan enam masalah besar. Sebagaimana yang diungkapkan oleh Institute for Development of Economics and Finance (Indef) yang mengemukakan bahwa beberapa persoalan yang dihadapi Indonesia yang perlu pemerintah perhatikan agar dapat memperbaiki pertumbuhan ekonomi yakni diantaranya; Pertama, resiko ketidakpastian ekonomi global. Dengan indikasi perlambatan ekonomi Cina yang akan terus berlanjut, perlu adanya reorientasi pasar ekspor khususnya sektor komoditas. Kedua, rendahnya daya beli masyarakat. Tingginya inflasi bahan makan tersebut berefek pada rendahnya konsumsi rumah tangga. Ketiga, menurunnya produktivitas nasional. Indef memaparkan, pertumbuhan sektor tradable tidak berkembang dan kurang berkontribusi menyerap tenaga kerja. Keempat, realisasi investasi tumbuh sangat rendah dari pembentukan modal domestik bruto akibat realisasi kredit yang melambat, serta infrastruktur dasar yang tidak tersedia. Kelima, meningkatnya pengangguran, kemiskinan, dan kesenjangan. Lemahnya sektor manufaktur dan pertambangan berdampak pada tingginya pengangguran. Keenam, ketergantungan pada 
ekspor komoditas. Ketujuh, efektivitas paket kebijakan fiskal dan moneter. Selain itu, pemerintah perlu menurunkan suku bunga Bank Indonesia sehingga berdampak pada bunga kredit dan meningkatkan kemampuan untuk membayar bagi masyarakat. Kedelapan, tantangan masyarakat ekonomi ASEAN. Menurut Indef, pemerintah perlu meningkatkan kualitas tenaga kerja Indonesia, dan berbenah agar mampu menarik investasi asing.

Pertumbuhan ekonomi berarti perkembangan kegiatan dalam perekonomian yang menyebabkan barang dan jasa yang diproduksikan dalam masyarakat bertambah dan kemakmuran masyarakat meningkat. Dalam hal ini berarti terdapatnya kenaikan dalam pendapatan nasional yang ditunjukkan oleh Produk Domestik Bruto (PDB), Sadono (1994). Terjadinya perlambatan pertumbuhan ekonomi tahun 2009 dengan persentase pertumbuhan 4,69\% lebih rendah daripada tahun sebelumnya. Hal ini disebabkan oleh kondisi perekonomian global yang masih mengalami tekanan akibat krisis menghadapkan perekonomian Indonesia pada sejumlah tantangan yang tidak ringan, kontraksi ekspor barang dan jasa yang cukup dalam yang menyebabkan menurunnya kepercayaan pelaku ekonomi di sektor keuangan dan sektor riil serta berpotensi menurunkan berbagai kinerja posistif yang telah dicapai dalam beberapa tahun sebelumnya. Pertumbuhan ekonomi tahun 2016 mengalami persentase pertumbuhan yang menurun yaitu sebesar $4.94 \%$ dengan nilai PDB sebesar Rp. 2.385.577,10 milyar, disebabkan oleh beberapa hal yaitu: 1. Efek perekonomian global. Kondisi perekonomian dunia yang belum stabil memberikan imbas besar pada ekonomi domestik. 2. Pemangkasan anggaran APBN. 3. Belanja pemerintah menurun (Nashrillah, 2016).

Kredit merupakan media perbankan yang akan berpengaruh terhadap perkembangan aktivitas perekonomian, dari sisi produksi perkembangan pembiayaan dalam bentuk kredit perbankan akan berpengaruh terhadap kemampuan produksi dunia usaha sehingga akan menentukan ouput riil dari berbagai sektor ekonomi. Makin banyak kredit berarti adanya kucuran dana dalam rangka meningkatkan usaha. Bagi pemerintah sendiri kredit merupakan keuntungan jika yang kredit yang disalurkan untuk keperluan ekspor, karena dengan itu para eksportir dapat berproduksi secara maksimal sehingga volume ekspor meningkat dan pada akhirnya bertambah pula cadangan devisa Negara (Fahrika, 2008). Pada tahun 2009 ekspansi kredit perbankan mengalami penurunan dibandingkan tahun 2008 yaitu sebesar 9,1\% dengan nilai total kredit sebesar 9,1\% disebabkan karena lambatnya penurunan suku bunga. Lambatnya penurunan suku bunga ini disebabkan oleh beberapa hal yaitu: 
Andi Ika Fahrika, Apakah Pengaruh Ekspansi Kredit Perbankan Dan Peranan Ekspor ...

1). tingginya cost of fund, 2). kenaikan biaya operasional perbankan, 3). tingginya resiko kredit bermasalah, 4). volume kredit mikro, kecil dan menengah (MKM) yang telah mengalami pertumbuhan yang cukup signifikan.

Tahun 2016 merupakan tahun yang baik bagi pertumbuhan kredit perbankan. Sebab jika dibandingkan tahun sebelumnya, pertumbuhan kredit bank cenderung lesu. Pertumbuhan kredit melemah di tahun 2016. Salah satu alasannya yakni investasi swasta yang belum meningkat.(Rakhma, 2017). Industri perbankan Indonesia dalam dua tahun berturut-turut, mengalami pelemahan fungsi intermediasi. Penyebab melemahnya aktivitas kredit perbankan karena kurangnya permintaan kredit oleh dunia usaha di tengah perlambatan ekonomi global, terutama melemahnya perekonomian Tiongkok, ditambah lagi) penurunan suku bunga kredit masih lambat, sebagai akibat perbankan melakukan pencadangan biaya. Hal ini sejalan dengan peningkatan rasio kredit bermasalah (NPL). (Nurhayat, 2017).

Ekspor sangat penting dalam menunjang perekonomian Indonesia, karena ekspor tidak saja sebagai sumber penerimaan devisa tetapi juga sebagai perluasan pasar bagi produksi barang-barang domestik. (Muhammad, 2007). Namun beberapa pertanyaan yang menarik menyangkut konsep manfaat perdagangan. Misalnya, mengapa perdagangan internasional tidak selalu menyebabkan pertumbuhan, atau mengapa pertumbuhan yang disebabkannya lebih sering hanya terbatas pada manfaat statis, tidak dinamis. Di beberapa negara berkembang pertumbuhan yang kuat dari ekspor telah gagal menyebar secara substansial pada sektor yang lain, dan dengan demikian tidak menimbulkan pembangunan yang lebih tersebar dalam perekonomian domestik. (Hakim, 2002)

Kredit merupakan media perbankan yang akan berpengaruh terhadap perkembangan aktifitas perekonomian, dari sisi produksi perkembangan pembiayaan dalam bentuk kredit perbankan akan berpengaruh terhadap kemampuan produksi dunia usaha sehingga akan menentukan output rill dari berbagai sektor ekonomi. Makin banyak kredit berarti adanya kucuran dana dalam rangka meningkatkan usaha. Bagi pemerintah sendiri, kredit merupakan keuntungan, jika kredit yang disalurkan untuk keperluan ekspor, karena dengan ini para eksportir dapat berproduksi secara maksimal sehingga volume ekspor meningkat yang pada akhirnya mengakibatkan bertambah cadangan devisa. Oleh karena itu, kebijakan perdagangan luar negeri diarahkan untuk mendukung upaya peningkatan daya saing global produk Indonesia, serta meningkatkan peranan ekspor dalam memacu pertumbuhan ekonomi. 


\section{TINJAUAN TEORITIK / LITERATURE REVIEW}

\section{Pertumbuhan Ekonomi}

Menurut Adam Smith dalam Boediono, (1985) bahwa ada dua aspek utama dari pertumbuhan ekonomi yaitu pertumbuhan output (GDP) total dan pertumbuhan ekonomi yaitu pertumbuhan output (GDP) total dan pertumbuhan penduduk. Pertumbuhan output Adam Smith melihat sistem produksi suatu negara terdiri dari tiga unsur pokok yaitu : 1). Sumber-sumber alam yang tersedia (atau faktor produksi tanah) 2). Sumber-sumber manusiawi (jumlah penduduk) 3). Stok barang kapital yang ada.

Dalam model Smith unsur produksi yang ketiga, yaitu stok capital yang secara aktif menentukan tingkat output. Smith memang memberikan peranan central kepada pertumbuhan stok capital atau akumulasi capital dalam proses pertumbuhan output. Apa yang terjadi dengan tingkat output, tergantung pada apa yang terjadi pada stok capital dan laju pertumbuhan output tergantung pada laju pertumbuhan stok capital (tentu saja sampai pada tahap pertumbuhan dimana sumber-sumber alam mulai membatasi).

Namun, hal yang cukup berbeda yang diungkapkan oleh Kuznets dalam Jhingan, (2010) bahwa pertumbuhan ekonomi adalah merupakan fenomena kenaikan jangka panjang dalam kemampuan suatu negara untuk menyediakan semakin banyak jenis barang-barang ekonomi kepada penduduknya; kemampuan ini tumbuh sesuai dengan kemajuan teknologi, dan penyesuaian kelembagaan dan ideologis yang diperlukannya.

Dalam perjalanan gagasan tentang pertumbuhan ekonomi tersebut dikembangkan oleh Harrord - Domar yang memperlihatkan dua aspek dari pembentukan modal dalam kegiatan ekonomi yaitu mempertinggi pengeluaran masyarakat dan mempertinggi jumlah alat-alat modal dalam masyarakat. Dalam teori Harrord-Domar pembentukan modal dipandang sebagai pengeluaran yang akan menambah kesanggupan suatu perekonomian untuk menghasilkan barang-barang maupun sebagai pengeluaran yang akan menambah permintaan efektif seluruh masyarakat. Teori Harrord - Domar menganggap pula bahwa penambahan dalam kesanggupan memproduksi ini tidak secara sendirinya akan menciptakan pertambahan produksi dan kenaikan pendapatan nasional.

Pengukuran PDB atau PDRB dapat dihitung melalui tiga cara, yaitu dengan cara pengeluaran, produk neto dan dengan cara pendapatan. Hal ini dapat dijelaskan antara lain: (Sukirno, 2004). 1). Cara Pengeluaran. Perhitungan pendapatan nasional dengan cara 
Andi Ika Fahrika, Apakah Pengaruh Ekspansi Kredit Perbankan Dan Peranan Ekspor ...

pengeluaran membedakan pengeluaran atas barang dan jasa yang dihasilkan dalam perekonomian 2). Cara Produk Neto. Produk neto (net output) berarti nilai tambah yang diciptakan dalam suatu proses produksi. 3). Cara Pendapatan. Perhitungan pendapatan dengan cara ini dengan menjumlahkan pendapatan-pendapatan dari faktor-faktor produksi yang digunakan.

Ryan, (2007) mengungkapkan bahwa pembangunan ekonomi di suatu negara sangat bergantung pada perkembangan dinamis dan kontribusi nyata dari sektor perbankan. Ketika sektor perbankan terpuruk, perekonomian nasional juga ikut terpuruk. Demikian pula sebaliknya, ketika perekonomian mengalami stagnasi, sector perbankan juga terkena imbasnya, dimana fungsi intermediasi tidak berjalan normal.

Herdiana, (2011) membenarkan bahwa Bank Umum (Commercial Bank) memiliki peranan yang sangat penting dalam menggerakkan roda perekonomian nasional, karena lebih dari 95\% Dana Pihak Ketiga (DPK) perbankan nasional yang meliputi Bank Umum (Commercial Bank), Bank Syariah dan Bank Perkreditan Rakyat berada di Bank Umum. DPK ini yang selanjutnya digunakan untuk mendorong pertumbuhan ekonomi melalui penyaluran kredit.

\section{Kredit Perbankan}

Untuk mencapai pertumbuhan ekonomi yang lebih baik, maka peranan pihak swasta sangat dibutuhkan. Peran pihak swasta tersebut dapat diwujudkan melalui pengerahan dana lewat perbankan. Oleh karena itu usaha untuk meningkatkan efisiensi dan efektivitas lembaga keuangan ini perlu digalakkan dalam mengerahkan dan menyalurkan dana.

Bank adalah lembaga keuangan (financial institution) yang berfungsi sebagai perantara keuangan (financial intermediary) antara pihak yang kelebihan dana (surplus unit) dan pihak yang kekurangan dana (déficit unit). Mellaui bank kelebihan dana tersebut dapat disalurkan kepada pihak - pihak yang memerlukan dan memberikan manfaat bagi kedua belah pihak. Bank menerima simpanan uang dan masyarakat (Dana Pihak Ketiga) dan kemudian menyalurkannya kembali dalam bentuk kredit.

Negara-negara seperti Indonesia, peranan bank cenderung lebih penting dalam pembangunan, karena bukan hanya sebagai sumber pembiayaan tetapi juga mampu mempengaruhi usaha-usaha dalam perekonomian secara keseluruhan. Hal ini dilaksanakan bank lebih superior dibandingkan dengan lembaga keuangan lainnya dalam menghadapi informasi yang asimetris dan mahalnya biaya dalam melakukan fungsi intermediasi.

Menurut UUD No. 7 tahun 1992 tentang perbankan adalah "Penyediaan uang atau tagihan yang dapat dipersamakan dengan itu, berdasarkan persetujuan kesepakatan 
pinjam-meminjam antar bank dengan pihak lain yang mewajibkan pihak meminjam untuk melunasi hutangnya setelah jangka waktu tertentu dengan jumlah bunga, imbalan atau pembagian hasil keuntungan".(Etika, $\left.{ }^{2011}\right)$.

Tujuan kredit yang diberikan oleh Bank khususnya bank pemerintah yang mengemban tugas sebagai Agen of Development adalah sebagai berikut: a). Turut mensukseskan program pemerintah di bidang ekonomi dan pembangunan b). Meningkatkan aktivitas perusahaan agar dapat menjalankan fungsinya guna menjamin terpenuhinya kebutuhan masyarakat c). Memperoleh laba agar kelangsungan hidup perusahaan terjamin dapat memperluas usahanya. (Herdiana, 2011).

Kredit perbankan mempunyai fungsi sebagai berikut : a). Meningkatkan daya guna uang b). Meningkatkan peredaran dan lalu lintas uang c). Meningkatkan daya guna dan peredaran uang d). Sebagai salah satu alat stabilitas ekonomi e). Meningkatkan kegairahan dalam berusaha f). Meningkatkan pemerataan pendapatan g). Meningkatkan hubungan internasional. Kredit menurut jenis yang dibiayai terdiri dari Kredit Modal Kerja, Kredit Investasi dan Kredit Konsumsi.

Kredit bukan saja memiliki tujuan positif tetapi juga memiliki dampak negatif. Adapun dampak negatif kredit yaitu : 1 . Mendorong masyarakat hidup konsumtif (boros) 2 . Mendorong inflasi, karena dengan kredit uang beredar semakin banyak melebihi jumlah barang kebutuhan hidup akibatnya harga cenderung untuk terus naik. 3. Bermunculan spekulan-spekulan, dengan adanya kredit orang banyak berspekulasi akibatnya banyak transaksi, tetapi tidak diikuti kemampuan membayar. 4. Bermunculan renternir yang menjerat rakyat ke dalam kemiskinan. 5. Mendorong produksi berlebihan karena kredit tidak diikuti manajemen perusahaan yang baik akibatnya perusahaan rugi.

Kredit menurut lembaga pemberi - penerima kredit yang menyangkut struktur pelaksanaan kredit yaitu : 1. Kredit Perbankan kepada masyarakat untuk kegiatan usaha, dan atau konsumsi. 2. Kredit Likuiditas, yaitu kredit yang diberikan oleh Bank Sentral kepada bank-bank yang beroperasi di Indonesia, yang selanjutnya akan digunakan sebagai dana untuk membiayai kegiatan perkreditannya. 3. Kredit Langsung, kredit ini diberikan oleh Bank Indonesia kepada lembaga pemerintah atau semi pemerintah. Misalnya Bank Indonesia memberikan kredit kepada Bulog dalam rangka pelaksanaan program pengadaan pangan. 
Andi Ika Fahrika, Apakah Pengaruh Ekspansi Kredit Perbankan Dan Peranan Ekspor ...

\section{Ekspor}

Menurut Priadi (2000) dalam Mankiw bahwa ekspor adalah sistema perdagangan dengan cara mengeluarkan barang-barang dari dalam negeri ke luar negeri untuk memenuhi ketentuan yang berlaku. Menurut Mankiw ekspor adalah penjualan berbagai macam barang dan jasa yang diproduksi di dalam negeri ke luar negeri. Pengembangan ekspor, terutama ekspor non migas, baik barang maupun jasa pada dasarnya merupakan andalan dalam jangka pendek bagi pemulihan ekonomi dan jangka menengah untuk terus meningkatkan perekonomian nasional sekaligus cadangan devisa. Perdagangan internasional sering disebut sebagai motor pertumbuhan ekonomi yang menggerakkan pembangunan ekonomi negaranegara maju. Perdagangan internasional menjanjikan banyak keuntungan, dalam rangka meningkatkan standar hidup penduduk. Mereka mengimpor dan mengekspor berbagai barang dan jasa serta modal.

Menurut Jhingan, (2010) bahwa ekspor merupakan faktor penting dalam merangsang pertumbuhan ekonomi suatu negara. Ekspor akan memperbesar kapasitas konsumsi suatu negara meningkatkan output dunia, serta menyajikan akses ke sumbersumber daya yang langka dan pasar-pasar internasional yang potensial untuk berbagai produk ekspor yang mana tanpa produk-produk tersebut, maka negara-negara miskin tidak akan mampu mengembangkan kegiatan dan kehidupan perekonomian nasionalnya. Ekspor juga dapat membantu semua negara dalam menjalankan usaha-usaha pembangunan mereka melalui promosi serta penguatan sektor-sektor ekonomi yang mengandung keunggulan komparatif. Ekspor juga dapat membantu semua negara dalam mengambil keuntungan dari skala ekonomi yang mereka miliki. (Todaro, 2006). Fungsi penting komponen ekspor dari perdagangan luar negeri adalah negara memperoleh keuntungan dan pendapatan nasional naik, yang pada gilirannya menaikkan jumlah output dan laju pertumbuhan ekonomi. Dengan tingkat output yang lebih tinggi lingkaran setan kemiskinan dapat dipatahkan dan pembangunan ekonomi dapat ditingkatkan. Ekspor memiliki manfaat sebagai berikut 1). Meningkatkan Daya Saing 2). Meningkatkan Keuntungan Bisnis 3). Meningkatkan Skala Produksi 4). Membuka Peluang Pasar yang Luas 5). Menghindari Pasar Domestik yang Terlalu Tinggi 6). Meningkatkan Nilai Investasi 7). Meningkatkan Hubungan Kerjasama Internasional. Ekspor dan impor juga menjadi salah satu langkah yang penting untuk meningkatkan hubungan kerjasama. Fungsi penting komponen ekspor dari perdagangan luar negeri adalah negara memperoleh keuntungan dan pendapatan nasional naik, yang pada gilirannya menaikkan jumlah output dan laju pertumbuhan ekonomi. 
Terdapat beberapa faktor yang menjadi pendorong semua negara di dunia untuk melakukan perdagangan luar negeri. Dari faktor-faktor tersebut empat yang terpenting dinyatakan di bawah ini: a). Memperoleh barang yang tidak dapat dihasilkan di dalam negeri b). Mengimpor teknologi yang lebih modern dari negara lain $\mathrm{c})$. Memperluas pasar produk-produk dalam negeri d). Memperoleh keuntungan dari spesialisai (Sukirno, 2004)

A. Hipotesis Hubungan antara Ekspor dan Pertumbuhan Ekonomi

Terkait dengan hubungan antara ekspor dan pertumbuhan ekonomi, Jung and Marshall (1985) mengemukakan bahwa dalam hubungan antara ekspor dan pertumbuhan ekonomi, setidaknya ada empat hipotesis atau pandangan yang sama-sama masuk akal (plausible) dan dapat diterima. (Nasrullah, 2014).

1. Hipotesis Export Led Growth (Export Optimism).

Hipotesis ekspor sebagai motor pengerak bagi pertumbuhan ekonomi dan merupakan keharusan dari setiap negara yang ingin maju karena beberapa alasan, antara lain ekspor dapat menyebabkan penggunaan penuh sumber-sumber domestik sesuai dengan keunggulan komparatif (comparative advantage) dan terjadinya pembagian kerja sehingga mendorong terjadinya skala penghematan (economic scale), ekspor dapat memperluas pasar baik di dalam negeri maupun luar negeri, ekspor merupakan sarana untuk mengadopsi ide atau pengetahuan baru, teknologi baru, keahlian baru, serta keahlian lainnya sehingga memungkinkan penggunaan kapasitas lebih besar dan lebih efisien, ekspor dapat mendorong mengalirnya modal dari negara-negara maju ke negara-negara sedang berkembang, ekspor merupakan salah satu cara yang efektif untuk menghilangkan perilaku monopoli, karena produsen dalam negeri dituntut untuk lebih efisien sehingga dapat bersaing dengan produsen lain di luar negeri, adanya ekspansi ekspor akan menghasilkan devisa dan karenanya kesempatan mengimpor barang-barang modal (capital goods) dan barang-barang antara (intermediate goods) semakin besar pula. Oleh karena itu, ekspor merupakan faktor penyebab naiknya pertumbuhan ekonomi.

Beberapa tokoh yang mendukung hipotesis Export Led Growth adalah Gerald K. H. (1964), Krueger (1978), penelitian World Bank (1987), Marc Piazolo (1995), dan lain-lain.

2. Hipotesis Export Reducing Growth (Export Pessimism)

Hipotesis ekspor sebagai mesin bagi pertumbuhan ekonomi. Mekanisme ini dalam perspektif kaum pesimis, hanya terjadi dalam jangka pendek, khususnya pada negaranegara sedang berkembang. Akan tetapi dalam jangka panjang, ekspor bukanlah resep 
yang mujarab untuk menyelesaikan masalah pembangunan di negara-negara sedang berkembang, karena ekspor akan menyebabkan perekonomian di negara-negara sedang berkembang menjadi rentan terhadap fluktuasi perekonomian dunia, adanya proteksi dan produk-produk sintesis yang dibuat oleh negara-negara maju untuk menggantikan barangbarang alami (bahan mentah dari negara sedang berkembang), struktur ekonomi dualistik dalam perekonomian negara sedang berkembang pada umumnya.

Beberapa tokoh yang mendukung hipotesis Export Reducing Growth adalah Raul P. (1950), Hans W. S. (1950), Emmanuel (1972), dan lain-lain.

3. Hipotesis Internally Generated Export (Growth Optimism)

Hipotesis ini menyatakan bahwa syarat utama bagi suatu negara dalam melakukan ekspor adalah menciptakan iklim yang dapat membawa terjadinya proses pertumbuhan ekonomi dalam negeri yang berkesinambungan (self generating) melalui pembentukan dan perluasan pasaran dalam negeri yang kokoh. Sehingga ekspor bukan merupakan motor penggerak bagi pertumbuhan ekonomi dalam negeri, tetapi sebaliknya, pertumbuhan ekonomi dalam negeri merupakan penggerak bagi ekspor. Beberapa tokoh yang mendukung hipotesis Internally Generated Export adalah Boltho (1996), K. Ohkawa dan H. Rosovsky (1996), dan lain-lain.

4. Hipotesis Growth Reducing Export (Growth Pessimism)

Hipotesis yang menyatakan bahwa selama kehidupan sosial dan budaya serta pranata sosial masyarakat suatu negara (negara-negara sedang berkembang) masih rapuh, tidak mustahil pertumbuhan ekonomi justru akan menyebabkan turunnya ekspor. Beberapa tokoh yang mendukung hipotesis Growth Reducing Export adalah Robert J. Barro dan Xavier Sala-I-Martin (1994), dan lain-lain.

B. Teori Perdagangan Internasional

Para penganut merkantilisme berpendapat bahwa satu-satunya cara bagi sebuah negara untuk menjadi kaya dan kuat adalah dengan melakukan sebanyak mungkin ekspor dan sedikit impor (Salvator, 1997).

1. Teori Keunggulan Absolut

Menurut Adam Smith perdagangan dua negara didasarkan kepada keunggulan absolut (absolute advantage), yaitu jika sebuah negara lebih efisien daripada negara lain dalam memproduksi sebuah komoditi, namun kurang efisien dibanding negara lain dalam memproduksi komoditi lainnya, maka kedua negara tersebut dapat memperoleh keuntungan dengan cara masing-masing melakukan spesialisasi dan memproduksi komoditi yang memiliki keunggulan absolut (Salvator, 1997). Melalui proses ini, sumber daya di kedua 
negara dapat digunakan dengan cara yang paling efisien. Output yang diproduksi pun akan menjadi meningkat.

\section{Teori Keunggulan Komparatif'}

Menurut David Ricardo yang ditulis bukunya Principle of Political Economy and Taxation tahun 1817 (Salvator, 1997), meskipun suatu negara kurang efisien dibanding (atau memiliki kerugian absolut) dengan negara lain dalam memproduksi dua komoditi, namun masih tetap terdapat dasar untuk dapat melakukan perdagangan yang menguntungkan kedua belah pihak. Negara tersebut harus melakukan spesialisasi dalam memproduksi dan mengekspor komoditi yang memiliki kerugian absolut lebih kecil (ini adalah komoditi dengan keunggulan komparatif) dan mengimpor komoditi yang memiliki kerugian absolut lebih besar (komoditi ini memiliki kerugian komparatif).

3. Teori Modern; Proporsi Faktor Produksi

Teori Faktor Proporsi (factor proportion) dari Heckscher Ohlin disebut juga teori modern. Dasar pemikirannya adalah bahwa perdagangan internasional semisal antara dua negara terjadi karena adanya opportunity cost yang berbeda antara kedua negara tersebut.

4. Teori Keunggulan Kompetitif

Menurut Michael E. Porter (1990) The Competitive Advantage of Nation adalah tentang tidak adanya korelasi langsung antara dua faktor poduksi (sumber daya alam yang tinggi dan sumber daya manusia yang murah) yang dimiliki suatu negara untuk dimanfaatkan menjadi data saing dalam perdagangan.

5. Teori Perdagangan dengan Permintaan dan Penawaran

Faktor-faktor yang menyebabkan terjadinya perdagangan internasional adalah karena adanya perbedaan permintaan dan penawaran suatu negara. Perbedaan ini terjadi karena: (a) tidak semua negara memiliki dan mampu menghasilkan komoditi yang diperdagangkan, karena faktor-faktor alam negara tersebut tidak mendukunng, seperti letak geografis dan kandungan buminya, dan (b) perbedaan pada kemampuan suatu negara dalam menyerap komoditi tertentu pada tingkat yang lebih efisien.

C. Penghambat Perdagangan Internasional

Penghambat impor (import barriers) adalah langkah-langkah pemerintah dalam perpajakan atau peraturan-peraturan impor yang mengurangi kebebasan perdagangan luar negeri. Penghambat impor biasanya dibedakan menjadi atas dua jenis, yaitu: 
Andi Ika Fahrika, Apakah Pengaruh Ekspansi Kredit Perbankan Dan Peranan Ekspor ...

a. Tariff

Tariff adalah pembebanan pajak atau custom duties terhadap barang-barang yang melewati batas suatu negara. Dilihat dari aspek asal komoditi, ada dua macam tariff, yaitu (Salvatore, 1997): 1) Tariff impor, yakni pajak yang dikenakan untuk setiap komoditi yang diimpor dari negara lain. 2) Tariff ekspor, yakni pajak untuk suatu komoditi yang dieskpor.

b. Penghambat bukan tariff

Salah satu bentuk hambatan bukan tariff adalah kuota. Kuota adalah pembatasan secara langsung jumlah fisik terhadap barang yang masuk (kuota impor) dan keluar (kuota ekspor). Pemberlakuan kuota impor memberikan dampak-dampak terhadap konsumsi dan produksi seperti yang ditimbulkan oleh penerapan tariff impor yang setara.

\section{METODE PENELITIAN / METHODS}

Untuk mendapatkan data yang diperlukan dalam penelitian ini, maka kegiatan pengumpulan data dilakukan dengan mendatangi kantot Badan Pusat Statistik dan Bank Indonesia dan Kantor Otoritas Jasa Keuangan (OJK)

b). Jenis Penelitian

Penelitian ini merupakan eksplanasi (explanatory research) dengan mengadakan analisis data sekunder yang berupa data time series yang bertujuan untuk memberikan penjelasan tentang pengaruh ekspansi kredit perbankan terhadap pertumbuhan ekonomi: analisis peranan ekspor di Indonesia tahun 2002-2016.

c). Jenis dan Sumber Data

Data yang digunakan dalam penelitian ini adalah data sekunder berbentuk time series di Indonesia dari tahun 2002 sampai tahun 2016 meliputi: kredit perbankan, ekspor dan pertumbuhan ekonomi di Indonesia melalui laporan-laporan dan dokumen-dokumen dari berbagai instansi terkait seperti kantor Badan Pusat Statistik dan Bank Indonesia.

d). Metode Pengumpulan Data

Untuk memperoleh data yang diperlukan dalam penelitian ini, maka digunakan teknik pengumpulan data yaitu Riset Kepustakaan (Library Research). Dalam hal ini bertujuan untuk mendapatkan dasar-dasar teoritis mengenai hal-hal yang akan diteliti, baik bukubuku, laporan-laporan ataupun sejenisnya yang didokumentasikan oleh pemerintah atau pihak-pihak tertentu melalui Badan Pusat Statistik dan Bank Indonesia.

e). Metode Analisis 
Berdasarkan model structural pada kerangka pikir di atas (gambar 2.2), maka dapat dibentuk persamaan fungsional dalam model simultan (Structural Equation Modelling, SEM) dengan reduced form sebagai berikut : (1). $Y 1=f(X 1) \quad$ (2). $Y 2=f(X 1, Y 1$,$) , dimana: X 1=$ Kredit Perbankan, Y1 = Ekspor dan Y2 = Pertumbuhan Ekonomi

1. Evaluasi Kriteria Goodness of Fit

Penolakan dan Penerimaan Model. Beberapa kriteria penerimaan atau menolak model dapat dilihat pada tabel 1 sebagai berikut :

\begin{tabular}{|c|c|c|c|}
\hline No & Kriteria & Cut-off & Keterangan \\
\hline 1 & $\begin{array}{ll}\text { Chi } & \text { Square } \\
\left(X^{2}\right) & \end{array}$ & $\begin{array}{l}\text { Non Signifikan tergantung } \\
\text { tingkat a }\end{array}$ & $\begin{array}{l}\text { Chi Kuadrat tidak jauh berbeda dengan } \\
\text { derajat bebas }\end{array}$ \\
\hline 2 & RMR & Mendekati nol & Digunakan untuk $\mathrm{n}$ besar \\
\hline 3 & RMSEA & $\leq 0.080$ & Digunakan untuk $\mathrm{n}$ besar \\
\hline 4 & GFI & $\geq 0.90$ & Mirip dengan $\mathrm{R}^{2}$ dalam regresi \\
\hline 5 & AGFI & $\geq 0.90$ & Mirip dengan $\mathrm{R}^{2}$ adjusted dalam regresi \\
\hline 6 & CFI & $\geq 0.94$ & Tidak sensitif terhadap besar sampel \\
\hline 7 & AIC & Mendekati nol & Pilih yang nilainya terkecil \\
\hline
\end{tabular}

Selanjutnya untuk menentukan apakah hasil estimasi parameter dalam Structural Equation Modelling signifikan atau tidak dilakukan dengan menggunakan uji t. Mengingat estimasi model dilakukan dengan SEM melalui software AMOS 2.0 maka kriteria penerimaan atau penolakan hipotesis statistik adalah : a). Tolak HO jika nilai probabilita (p) parameter antar variabel yang diuji lebih kecil dari tingkat a (0.05) b). Terima HO jika nilai probabilita (p) parameter variabel yang diuji lebih besar dari tingkat a (0.05).

\section{HASIL DAN PEMBAHASAN / DISCUSSION}

\section{Pengaruh Langsung Kredit Perbankan terhadap Ekspor}

Dari hasil analisis jalur pada dapat diketahui bobot koefisien regresi kredit perbankan terhadap ekspor adalah sebesar 0,502 dengan nilai $\mathrm{p}^{* * *}(* * *<0,05)$ dan C.R. $(3,581>$ 1,96). Hal ini berarti kredit perbankan berpengaruh secara langsung terhadap ekspor. Dengan koefisien regresi yang bernilai positif $(0,502)$, menunjukkan bahwa apabila kredit perbankan ditingkatkan secara optimal sampai 100\%, maka ekspor akan meningkat pula sebesar $50,2 \%$. 
Andi Ika Fahrika, Apakah Pengaruh Ekspansi Kredit Perbankan Dan Peranan Ekspor ...

Bagi investasi dalam negeri, restrukturisasi perbankan dan utang menjadi penentu, karena kembalinya peranan perbankan dalam menyalurkan kredit dan penyelesaian permasalahan utang korporat akan mendorong kegiatan investasi dalam negeri. Untuk itu diperlukan kerja sama yang erat antara otoritas moneter dan pemerintah guna membantu peningkatan investasi dengan pemberian kemudahan kredit perbankan guna mendongkrak ekspor.

b). Pengaruh Langsung Kredit Perbankan terhadap Pertumbuhan Ekonomi

Dari hasil analisis jalur dapat diketahui bobot koefisien regresi kredit perbankan terhadap pertumbuhan ekonomi adalah sebesar 0,335 dengan nilai $p=0,006$ $(0,006<0,05)$ dan C.R. $(2,753>1,96)$. Hal ini berarti kredit perbankan berpengaruh positif secara langsung dan signifikan terhadap pertumbuhan ekonomi. Dengan koefisien regresi yang bernilai positif $(0,335)$, menunjukkan bahwa apabila kredit perbankan ditingkatkan secara optimal sampai $100 \%$, maka pertumbuhan ekonomi akan meningkat pula sebesar $33,5 \%$.

Secara teori, kredit perbankan memiliki hubungan kausalitas yang positif dengan pertumbuhan ekonomi. Hubungan timbal balik tersebut terjadi karena semakin tinggi kredit yang disalurkan oleh pihak perbankan, maka akan memacu pertumbuhan ekonomi pada sektor yang disalurkan kredit dan akhirnya dapat meningkatkan pertumbuhan ekonomi.

c). Pengaruh Langsung Ekspor terhadap Pertumbuhan Ekonomi

Dari hasil analisis jalur dapat diketahui bobot koefisien regresi ekspor terhadap pertumbuhan ekonomi adalah sebesar $-0,094$ dengan nilai $p=0,474(0,474>$ $0,05)$ dan C.R. $(-0,715<1,96)$. Hal ini berarti ekspor tidak berpengaruh secara langsung dan berpengaruh negatif terhadap pertumbuhan ekonomi.

Temuan penulis dari studi yang dilakukan, hasil estimasi menunjukkan bahwa ekspor berpengaruh negatif signifikan terhadap pertumbuhan ekonomi. Hal ini tidak sejalan dan tidak sesuai dengan hipotesis yang dikemukakan pada bab II. Dalam teori perdagangan internasional (Heckescher-Ohlin) menyebutkan bahwa Net-Ekspor atau ekspor netto merupakan salah satu faktor terpenting dari Gross National Product (GNP), sehingga dengan berubahnya nilai Net-Ekspor maka akan memberikan pengaruh terhadap perubahan dari pendapatan nasional.

Dari hasil statistik yang penulis kemukakan maka bisa disimpulkan bahwa selama periode 2002-2016 hubungan antara net-ekspor dan pertumbuhan ekonomi Indonesia sejalan dengan hipotesis ekspor merupakan penyebab turunnya pertumbuhan ekonomi 
(export-reducing growth hypothesis). Dalam Jurnal Ekonomi dan Bisnis Indonesia yang ditulis oleh Aliman dan A. Budi Purnomo mengenai kausalitas antara ekspor dan pertumbuhan ekonomi menyatakan bahwa Hipotesis Export Reducing Growth (Export Pessimism) menyebutkan bahwa hipotesis ekspor sebagai mesin bagi pertumbuhan ekonomi; mekanisme ini dalam perspektif kaum pesimis, hanya terjadi dalam jangka pendek, khususnya pada negara-negara sedang berkembang, akan tetapi dalam jangka panjang, ekspor bukanlah resep yang mujarab untuk menyelesaikan masalah pembangunan di negara-negara sedang berkembang, karena ekspor akan menyebabkan perekonomian di negara-negara sedang berkembang menjadi rentan terhadap fluktuasi perekonomian dunia, adanya proteksi dan produk-produk sintesis yang dibuat oleh negara-negara maju untuk menggantikan barang-barang alami (bahan mentah dari negara sedang berkembang), struktur ekonomi dualistik dalam perekonomian negara sedang berkembang pada umumnya. Beberapa tokoh yang mendukung hipotesis Export Reducing Growth adalah Raul P. (1950), Hans W. S. (1950), Emmanuel (1972), dan lain-lain. (Purnomo, 2001).

Net Ekspor memiliki pengaruh negatif signifikan terhadap pertumbuhan ekonomi. Hal itu terjadi karena peningkatan Net ekspor akan menyebabkan international reserve meningkat sehingga money supply meningkat dan pada akhirnya akan meningkatkan permintaan agregat dan pertumbuhan ekonomi. Peningkatan permintaan agregat tersebut menyebabkan harga-harga domestik naik sehingga dalam jangka panjang terjadi penurunan permintaan agregat dan pertumbuhan ekonomi. Variabel Net Ekspor riil memiliki pengaruh yang paling kecil terhadap PDB. Hal itu mengindikasikan bahwa perdagangan internasional yang terjadi antara Indonesia dan mitra dagangnya belum memberikan kontribusi yang besar dalam peningkatan PDB. Komoditi ekspor Indonesia hingga saat ini masih bertumpu pada produk primer yang kurang memiliki nilai tambah. Selain itu elastisitas produk primer yang di ekspor Indonesia masih kurang sehingga apabila terjadi defisit pada neraca perdagangan, maka intervensi pemerintah melalui devaluasi nilai tukar tidak akan efektif.

Selain itu hasil ini diperkuat bahwa selama ini Indonesia masih mengimpor barang atau jasa yang sifatnya menjadi barang konsumtif bagi masyarakat sehingga aliran dana di dalam negeri beralih ke luar negeri sebagai akibat kegiatan impor barang dan jasa.

\section{Pengaruh Kredit Perbankan terhadap Pertumbuhan Ekonomi melalui Ekspor}

Dari hasil analisis mediating intervening dapat diketahui bobot regresi kredit perbankan terhadap pertumbuhan ekonomi adalah sebesar 0,222 dengan nilai $p$ sebesar 
0,023 $(0,028<0,05)$ dan C.R $(2,185>1,96)$. Hal ini berarti kredit perbankan berpengaruh secara tidak langsung (melalui ekspor) terhadap pertumbuhan ekonomi.

Jenis kredit dilihat dari dari segi tujuan kredit salah satunya adalah kredit perdagangan. Kredit perdagangan merupakan kredit yang diberikan kepada pedagang dan digunakan untuk membiayai aktifitas perdagangannya seperti untuk membeli barang dagangan yang pembayarannya diharapkan dari hasil penjualan barang dagangan tersebut, kredit ini sering diberikan kepada supplier atau agen-agen perdagangan yang akan membeli barang dalam jumlah besar seperti ekspor dan impor. (Kasmir, 2002).

Maka dari itu, hubungan kredit dan volume ekspor itu sendiri yakni semakin tinggi pemberian kredit maka akan semakin tinggi pula volume ekspor. Keuntungan kredit bagi pemerintah salah satunya adalah meningkatkan devisa negara apabila produk dari kredit yang dibiayai untuk keperluan ekspor. Interaksi antara perbankan dengan para pelaku ekonomi secara langsung melalui penyaluran kredit perbankan akan berpengaruh terhadap perkembangan aktifitas perekonomian. Dari sisi produksi perkembangan pembiayaan dalam bentuk kredit perbankan akan berpengaruh terhadap kemampuan produksi dunia usaha sehingga akan menentukan output riil dari berbagai sektor ekonomi. (Kasmir, 2002).

Bagi pemerintah sendiri kredit merupakan keuntungan jika yang kredit yang disalurkan untuk keperluan ekspor, karena dengan itu para eksportir dapat berproduksi secara maksimal sehingga volume ekspor meningkat dan pada akhirnya bertambah pula cadangan devisa negara.

\section{KESIMPULAN / CONCLUSION}

Kredit perbankan berpengaruh positif secara langsung dan signifikan terhadap ekspor. Apabila kredit perbankan meningkat, maka ekspor akan meningkat pula. Pengerahan dana lewat perbankan sangat penting untuk meningkatkan kegiatan ekspor karena kredit perbankan ini dipakai untuk pembiayaan kegiatan ekspor di Indonesia. Kucuran kredit ini untuk menunjang pertumbuhan ekspor Indonesia yang pada gilirannya akan menggerakkan ekonomi Indonesia.

Kredit perbankan berpengaruh positif secara langsung dan signifikan terhadap pertumbuhan ekonomi. Apabila kredit perbankan ditingkatkan secara optimal maka pertumbuhan ekonomi akan meningkat pula. Ini berindikasi bahwa kebijakan kredit perbankan di Indonesia telah mampu mendorong pertumbuhan ekonomi.

Ekspor tidak berpengaruh secara langsung dan berpengaruh negatif terhadap pertumbuhan ekonomi, dengan kata lain ketika terjadi peningkatan ekspor maka 


\section{Jurnal Ifeces}

Volume 5 Nomor1 Ed.Juni 2018 : page 99-119 p-ISSN: 2407-6635 e-ISSN : 2580-5570

pertumbuhan ekonomi akan menurun. Ekspor sebagai mesin penggerak pertumbuhan ekonomi hanya terjadi dalam jangka pendek, khususnya pada negara-negara sedang berkembang. Akan tetapi dalam jangka panjang, ekspor tidak dapat menyelesaikan masalah pembangunan di negara-negara sedang berkembang, karena ekspor akan menyebabkan perekonomian di negara-negara sedang berkembang menjadi rentan terhadap fluktuasi perekonomian dunia, adanya proteksi dan produk-produk sintesis yang dibuat oleh negaranegara maju untuk menggantikan barang-barang alami (bahan mentah dari negara sedang berkembang), struktur ekonomi dualistik dalam perekonomian negara sedang berkembang pada umumnya.

Kredit perbankan berpengaruh secara tidak langsung (melalui ekspor) terhadap pertumbuhan ekonomi. Untuk mencapai pertumbuhan ekonomi yang lebih baik, peranan pihak perbankan sangat dibutuhkan untuk kegiatan ekspor. Ketika penyaluran kredit perbankan untuk kegiatan ekspor meningkat, maka akan mendorong peningkatan kegiatan ekspor yang selanjutnya ekspor yang meningkat ini akan memacu peningkatan pertumbuhan ekonomi.

\section{DAFTAR PUSTAKA / REFERENCES}

Antaranews. Pertumbuhan Ekspor Indonesia 2009 Turun Drastis. http://m.antaranews.com/berita126222/pertumbuhan-ekspor-indonesia-2009turundrastis, Beijing, 2009.

Badan Pusat Statistik, Nilai Ekspor-Impor Indonesia (Juta US\$). https://www.bps.go.id/linkTabelStatis/view/id/1002, Jakarta, 2017.

Bapenas, Kerangka Ekonomi Makro; Lingkungan Internal dan Eksternal Tahun 2005-2006, www.bappenas.go.id/.../view=6/bab\%2011\%20\%20kerangka\%20ekonomi\%20m akro.pdf, Jakarta, 2002.

Prospek Ekonomi Tahun 2004, http://www.bappenas

Jakarta.go.id/index.php?module=Filemanager\&func=download\&pathext=ContentE xpress/\&view=6/BAB-III.pdf.,Jakarta, 2003

Penjelasan Atas Rancangan Undang-Undang RI Nomor 26 Tahun 2003 Tentang APBN Tahun Anggaran 2003.www.bapenas.go./peraturan/uu26penjelasan_2003.htm, Jakarta, 2003

Basri, Faisal, Analisa Ekonomi. http://www.fiskal.depkeu.go.id//bapekki/berita\%20main/ /detailnews.asp?NewsID=N462619386, Jakarta, 2006. 
Andi Ika Fahrika, Apakah Pengaruh Ekspansi Kredit Perbankan Dan Peranan Ekspor ...

Boediono, Teori Pertumbuhan Ekonomi. Yogyakarta: BPFE, 1985.

Boediono, Teori Pertumbuhan Ekonomi., Seri Sinopsis PIE No. 4, Yogyakarta: BPFE, 1993.

Etika, Titik, Pengaruh Kredit Perbankan dan Kurs terhadap Volume Ekspor Indonesia Tahun 1986-2008. Jakarta: Program Studi Ilmu Ekonomi dan Studi Pembangunan, Fakultas Ekonomi dan Bisnis Islam UIN Syarif Hidayatullah, 2010.

Daruningsih, Purbasari, Tingkat Pertumbuhan Ekonomi di Indonesia Tahun 2006 Lebih Rendah. www.elshinta.com/v2003a/readnews;htmid=37399, Jakarta, 2007.

Dominick, Salvatore, Ekonomi Internasional, alih bahasa oleh Haris Munandar, Edisi 5 Cetakan I, Jakarta; Erlangga, 1997.

Fahrika, Andi Ika, Pengaruh Pengeluaran Pembangunan dan Tingkat Suku Bunga terhadap Pertumbuhan Ekonomi di Indonesia: Analisis Peranan Investasi Swasta dan Ekspor (1987-2006)". Makassar: Pascasarjana Unhas, 2008.

Financialanalist, Perbankan Indonesia dalam Masa Krisis 2008. http://www.google.co.id/amp/s/financialanalist.wordpress.com/2009/09/06/perba nkan-indonesia-dalam-masa-krisis-2008/amp/, Jakarta, 2009.

Gani, A. P. Arie, A, Peranan Kredit Perbankan dalam Memacu Pertumbuhan Ekonomi, Makassar: Program Pascasarjana Unhas, 1997.

Hamdani, Seluk Beluk Perdagangan Ekspor Impor, Jakarta: BUSHINDO, 2007.

Hakim, Abdul, Ekonomi Pembangunan. Yogyakarta; Ekonisia UII, 2003.

Helmoth, Andy, Perkembangan Kredit Perbankan di Indonesia Tahun 2000 - 2010. Jakarta. https://belajargo.wordpress.com/2011/03/20/perkembangan-kredit-perbankan-diindonesia -tahun-2000-2010/amp/, Jakarta, 2001.

Herdiana, Dyta, Pengaruh Konsumsi, Investasi dan Kredit Perbankan terhadap Pertumbuhan Ekonomi Indonesia Periode 1980-2010. Jakarta: Program Studi Ilmu Ekonomi dan Studi Pembangunan. Fakultas Ekonomi dan Bisnis Islam UIN Syarif Hidayatullah, 2011.

Hidayat, Khomarul, Persetujuan Kredit Bank Terus Meningkat. http://www.sinarharapan.co.id/ekonomi/Keuangan/2004/0802/keu1.html, Jakarta, 2003.

Indrawan, Rully, Prof. Dr. H, Evaluasi Ekonomi Tahun 2006. https://rullyindrawan.wordpress.com/2008/12/02/Evaluasi-ekonomi-tahun 2006/),Jakarta, 2008.

Jhingan, M.L. 2008. Ekonomi Pembangunan dan Perencanaan. Jakarta: PT. Raja Grafindo Persada, 2008.

Jhingan, M.L, Ekonomi Pembangunan dan Perencanaan, Jakarta: Rajawali Press, 2010 
Jung dan Marshall. 1985. Export, Growth and Causality In Developing Countries. Journal of Development Economics. Belanda, 1985.

Kabar Bisnis, Pertumbuhan Kredit, Perbankan RI melambat, ini penyebabnya.

http://googleweblight.com/?lite_url=http://www.kabarbisnis.com/read/2873596/p ertumbuhan-kredit-perbankan-ri-melambat--ini-penyebabnya\&ei-roDuPokt\&IC=idID\&s $=1 \& m=213 \&$ host $=w w w . g o o g l e . c o . i d \& t s=1495374418 \& s i g=A L N Z j$ WkBtF3RQy9QEQiDu77 w90SF-Kgncg, Jakarta, 2017.

Kadin, Laporan Ekonomi Bulanan; Edisi Februari. http://www. kadin_Indonesia.or.id/id/doc/LaporanEkonomiEdisiFebruari07 .pdf, Jakarta, 2007.

Kiryanto, Ryan, Langkah Terobosan Mendorong Ekspansi Kredit, Economic Review, Nomor 208 tahun 2007.

Latif, Syahid, Tren Suku Bunga Turun di 2012, http:www.google.co. id/amp/m.viva.co.id/amp/bisnis/279164-tren-penurunan-suku-bunga-menggeliatdi-2012, Jakarta, 2012.

Kasmir, S.E.,M.M, Dasar-Dasar Perbankan, Edisi Pertama: Cetakan Kedua, PT. RajaGrafindo Persada, Jakarta, 2002.

Kompas. Kredit Baru Mencapai Rp 218 Triliun www.kompas.com/kompascetak/0501/14/finansial/1499505.htm - 39k< Jakarta, 2005.

Proyeksi Perekonomian Tahun 2008 Lebih Cerah. http://www.bappenas.go.id/.../proyeksi\%20Perekonomian\%20Tahun\%202008\% 20\%Lebih\%20Cerah.htm_18k, Jakarta, 2007.

Kompas, Tahun 2013 Ekonomi Indonesia Hanya 5,78 Persen. http://bisniskeuangan.kompas.com/read/2014/02/05/1221161/tahun.2013.ekono mi.indonesia.hanya.5.78.persen, Jakarta, 2014.

BI: Kuartal III 2016, Pertumbuhan Kredit Masih Lemah. http://www.google.co.id /amp/s/app.kompas.com/amp/bisniskeuangan/read/2016/10/15/064844926/bi.ku artal.iii.2016. pertumbuhan.kredit.perbankan.masih.lemah, Jakarta, 2016.

Mankiw, Greogory, N, Pengantar Ekonomi Makro. Edisi ketiga. Salemba Empat. Jakarta, 2006.

Muhammad, Marie. Kebijakan Fiskal di Masa Krisis 1997. www.fiskal.depkeu.go.id/webbkf/kolom/detailkolom.asp?newsID+N67871021, Jakarta, 2007. 
Andi Ika Fahrika, Apakah Pengaruh Ekspansi Kredit Perbankan Dan Peranan Ekspor ...

Nashrillah, Faiz, Ekonomi Indonesia Turun di Kuartal Tiga 2016. Ini Penyebabnya. https://business.idntimes.com/economy/faiz-nashrillah/ penyebab-ekonomiindonesia-turun-di-kuartal-tiga/full, Jakarta, 2016.

Nasrullah, Analisis Pengaruh Perdagangan Internasional terhadap Pertumbuhan Ekonomi Indonesia Tahun 1999-2013, Makassar: Universitas Hasanuddin, 2014

Nurhayat, Wiji, Kendala Investasi di Indonesia Ada di Daerah. https://m.kumparan. com/wiji-nurhayat/kepala-bkpm-kendala-investasi-di-indonesia-ada-di-daerah, Jakarta, 2017.

Otoritas Jasa Keuangan (OJK). Statistik Perbankan Indonesia, http://www.ojk.go.id/id/ka nal/perbankan/data-dan-statistik/statistik-perbankanindonesia, /Default.aspx, Jakarta,2017.

Pratama, Billy Arma. Analisis Faktor-Faktor yang Mempengaruhi Kebijakan Penyaluran Kredit Perbankan (Studi pada Bank Umum di Indonesia Periode Tahun 2005-2009). Semarang: Program Pasca Sarjana Universitas Diponegoro, 2010.

Priadi, Perdagangan Internasional, BUSHINDO. Jakarta, 2000.

Propenas. Undang - Undang Republik Indonesia Nomor. 25 Tahun 2000 Tentang Program Pembangunan Nasional (Propenas) Tahun 2000-2004, Jakarta, 2001.

Purnomo, Budi dan Aliman. Kausalitas Antara Ekspor dan Pertumbuhan Ekonomi. Jurnal Ekonomi dan Bisnis Indonesia, Vol. 16, No. 2, pp. 122-137, 2001.

Rajagukguk, Ranto, Ekspor Indonesia Loyo, Inilah Penyebabnya, http://googleweblight.com /?lite_url=http://m.inilah.com/read/detail/1938233/ekspor-indonesia-loyo-inilahpenyebabnya\&ei+8YgpdUOg\&Ic =idID\&s $=1 \& \mathrm{~m}=213 \&$ host $=$ www.google.co.id \&ts $=$ 1502723562\&sig=ALNZjWnqVvInfdjEWwEVtvSrqb7JDhbXsg, Jakarta, 2016.

Rakhma, Sakinah. Menanti Bukti Optimisme Pertumbuhan Kredit Perbankan. http://ekonomi.kompas.com/read/2017/01/23/120000026/menanti.bukti.optimism e.pertumbuhan.kredit.perbankan, Jakarta, 2017.

Republika. Enam Kendala Dera Ekspor Indonesia. http://m.republika.co.id/ berita/ekonomi/bisnis/11/09/27/Is5ui2-enam-kendala-dera-ekspor-indonesia, Jakarta, 2011.

Republika. Ekspor-Impor Kembali Lesu. http://www.republika.co.id/berita/koran/halaman-1/ /16/10/18/of8e4625-eksporimpor-kembali-lesu, Jakarta, 2016.

Sakinah Rakhma, "Menanti Bukti Optimisme Pertumbuhan Kredit Perbankan", Dalam http://ekonomi.kompas.com/read/2017/01/23/120000026/menanti.bukti.optimism e.pertumbuhan.kredit.perbankan, 19 Mei 2017.

Samuelson, Paul A., dan Nordhaus, William D. Macroeconomics 17th Edition (Alih Bahasa: Gretta, dkk). Jakarta: PT. Media Global Edukasi, 2004. 
Solimun. Pengukuran Variabel dan Pemodelan Statistika Aplikasi SEM-AMOS. Malang: Fakultas MIPA dan Pascasarjana Universitas Brawijaya, 2004.

Statistik Perbankan Indonesia, Volume 9 No. 11. http://www.bi.go.id/id /statistik/perbankan/indonesia/Documents/OJKSPI\%20Des\%202013.pdf, Jakarta, 2011.

Sukirno, Sadono, Makroekonomi Teori Pengantar. Cetakan Kedua, Jakarta: PT RajaGrafindo Persada, 1994.

Sukirno Sadono, Makroekonomi, Edisi Kedua, Jakarta:PT. RajaGrafindo Persada, 2001

Sukirno, Sadono. 2004. Makroekonomi Teori Pengantar. Edisi Ketiga, Jakarta: PT Raja Grafindo Persada, 2004.

Suyatno, Thomas, dkk, Dasar - Dasar Perkreditan, Jakarta: Gramedia Pustaka Utama, 1995

Todaro, M. P. Pembangunan Ekonomi. Jakarta: Penerbit Erlangga, 2000.

Tempo. BI : Investasi 2006 Hanya Tumbuh 5-6 Persen, www.tempoInteraktif .com/hg/ekbis/2006/07/28/brk,20060728-80807.id.html-45-k-, Jakarta, 2006.

Untung, Budi, Kredit Perbankan di Indonesia. Yogyakarta: Penerbit Andi, 2000

Wijaya, Faried. Pengantar Ekonomi Mikro. Yogyakarta: BPFE, 1990

Woo S. Jung and Peyton J. Marshall. North-Holland. Export, Growth And Causality In Developing Countries, 1985, Journal of Development Economics 18 (1-12), 1985

Yunan, Analisis Faktor-Faktor Yang Mempengaruhi Pertumbuhan Ekonomi Indonesia. Medan: Program Studi Ilmu Ekonomi dan Studi Pembangunan. Pasca Sarjana. Universitas Sumatra Utara, 2009. 
